ENCYCLOPEEDIE Encyclopédie berbère

BERBERE

$27 \mid 2005$

27 | Kairouan - Kifan Bel-Ghomari

\title{
Kalaa de Beni Hammad
}

(voir Qala'a)

\section{OpenEdition}

\section{Journals}

Édition électronique

URL : http://journals.openedition.org/encyclopedieberbere/1311

DOI : 10.4000/encyclopedieberbere.1311

ISSN : 2262-7197

Éditeur

Peeters Publishers

Édition imprimée

Date de publication : 1 août 2005

Pagination : 4111

ISBN : 2-7449-0538-0

ISSN : 1015-7344

\section{Référence électronique}

"Kalaa de Beni Hammad », Encyclopédie berbère [En ligne], 27 | 2005, document K23, mis en ligne le 01 juin 2011, consulté le 25 septembre 2020. URL : http://journals.openedition.org/encyclopedieberbere/ 1311 ; DOI : https://doi.org/10.4000/encyclopedieberbere.1311

Ce document a été généré automatiquement le 25 septembre 2020.

(c) Tous droits réservés 


\section{Kalaa de Beni Hammad}

(voir Qala'a) 